\title{
The Status of European Citizenship: An Overview
}

\begin{abstract}
This chapter gives a swift overview of the workings and principal rights associated with European citizenship. Some insight into the historical evolution of the status is offered. The major entitlements are explained as well as important case-law. The aim is to provide an outline of the essentials of European citizenship for the purpose of understanding the arguments made in this book.
\end{abstract}

Keywords European citizenship · Brexit · United Kingdom · Freedom of movement $\cdot$ Right of residence $\cdot$ EU law $\cdot$ EU citizens' rights

The status of European citizenship was introduced in European law with the Maastricht Treaty in 1992. Let us see what steps were taken to establish this particular form of status civitatis that differs from the standard legal form of citizenship that we are used to consider equivalent to nationality. It is additional to having member state nationality. It entails a series of rights that nationals of member states would not enjoy if they were not European citizens. This confers a degree of independence to the content of the status. It is not, however, an autonomous status. Yet, member states are not fully autonomous in exercising discretion over who gets access to the status. This overview shows what makes European citizenship a status sui generis that is not constituted in the same way as nationality in unitary states or dual citizenship commonly found in federal systems. The aim of this chapter is

(C) The Author(s) 2017

P. Mindus, European Citizenship after Brexit, Palgrave Studies

in European Union Politics, DOI 10.1007/978-3-319-51774-2_2 
not to present European citizenship in an exhaustive manner but to shed light on some key aspects of the status that are important for the arguments made in the book.

\subsection{EU Citizenship: A Brief History}

\subsubsection{The Background}

The first practical steps towards EU citizenship were taken in the 1970s (Maas 2007). Following the Paris Summit in October 1972, it was suggested that a European identity would be needed to deepen integration. More precisely, for the committee chairman, Xavier Ortoli, the lack of a European identity was one of the weaknesses of the European Community. ${ }^{1}$ Following the summits in Copenhagen in 1973 and in Paris the following year, the issue of integration became more pressing. At the Copenhagen summit a document on European identity was drafted, in which, mostly in general terms, emphasis was laid on common cultural heritage. The political aim of strengthening integration between member states started taking shape during the next summit in Paris. It was suggested that the involvement in the integration process of the citizens of the member states could enhance a future European identity. From here came the idea of having a common status civitatis.

To be precise, at least since the 1960s, the idea of a European citizenship had been proposed on different occasions, albeit in a rather indefinite manner. For example, the vice president of the Commission Lionello Levi Sandri had argued for prioritising the free movement of persons over the free movement of goods as it would be a first step towards European citizenship. It was only in the course of the 1970s, in particular in the wake of the Paris Summit, that deepened integration started being spelled out in terms of citizenship. It resulted in the 1974 report on special rights by the Belgian Leo Tindemans. In this report it was recommended that certain rights should be attributed to the 'ressortissants' of the member states, that is, their nationals. They included the right to vote and stand in elections for the European Parliament and the establishment of a European passport, which would lead to the so-called passport policy. ${ }^{2}$ This report, however, did not claim the rights in question to be of European citizens, but to be necessary for a 'Europe of citizens." 3 Tindemans handed in the report on the 29th of December 1975 and the Commission started to look into the so-called question of special rights. ${ }^{4}$ 
Nevertheless, with the protection of special rights, a legal problem arose, given that European citizens would enjoy rights both in their state of origin and in their state of residence. European citizens, in other words, would not be subjected to the principle of naturalisation, then commonly applied, according to which one would lose one's original citizenship in case of naturalisation abroad. According to the Commission, in fact, there was a risk of reversed discrimination that would have resulted in EU citizens being more protected than the citizens of the host state. The result, unsurprisingly, was that the special rights policy had a rather limited impact.

Tindemans' ideas were later revived by the European Parliament that presented a series of resolutions on European integration, considering the possibility of ascribing special rights to citizens of member states. Mario Scelba presented a report entitled Granting special rights to the citizenship of the community before the Parliament in Strasbourg on the 16th of November 1977. Many practical implications were put on hold. Yet, universal suffrage was introduced in the election of the European Parliament in 1979, putting into a new light the phenomenon for which David Marquand coined the famous expression 'democratic deficit' (Marquand 1979). It was held that the institution of universal suffrage constituted an embryonic form of citizenship.

The still rather imprecise idea of European citizenship came to the fore again in February 1984, when, in preparation of the Fontainebleau intergovernmental conference, the European Parliament presented a draft Treaty on the European Union, in which explicit mention of European citizenship was made in terms similar to those later adopted. During the Fontainebleau summit on the 25th and 26th of June 1984, two committees were established: the ad hoc committee on 'The Europe of Citizens' directed by Pietro Adonnino and another committee on 'Institutional Affairs' directed by James Dooge. The Adonnino Committee drafted two reports that focused on the objectives to be achieved respectively in the short and in the long run. They were presented to the European Council in Brussels in March 1985 and in Milan in June of the same year. The Adonnino report left no great signs on the Single European Act, an amending treaty signed in Luxembourg on the 17th of February 1986. Its preamble only makes a vague reference to European citizenship (Sébastien 1993).

It was only later, at the summit in Madrid on the 25th and 26th of June 1989, that the political will to introduce European citizenship became 
tangible. The heads of state gathered in the Spanish capital stressed how the European Community had failed to realise 'the Europe of citizens.' Following the Martin report from February 1990, the European Parliament called for a specific formulation of rights of European citizenship to be included in the future Treaty of Maastricht. A memorandum was written by the Belgian Foreign Minister Eysken suggesting the adoption of a uniform electoral procedure for the election of the European Parliament, in addition to the right to vote in local elections for all EU citizens. Nevertheless, it was first and foremost Spain that pushed in the direction of adopting the new status civitatis at Maastricht.

In a letter to the President of the European Council, dated the 4th of May 1990, the Spanish Prime Minister Felipe Gonzalez suggested instituting a form of supranational citizenship as a step towards a future political union. According to this scenario, nationals of member states resident in other states than the one of which they hold nationality should not be cast as privileged foreigners. Rather, they had to be granted rights that were classified as 'special basic rights,' 'new dynamic rights' and 'protective rights.' Leaving aside the merit of classification that, to some extent is reminiscent of that of T.H. Marshall (1950) then very much en vogue, it is interesting to note that the first category included the right to freedom of movement, freedom of residence, participation in political life in the place of residence, while social, environmental and cultural rights were listed under 'new rights' and the third category included the protection of the soon-to-be-instituted European citizens outside the Community. The Spanish memorandum came to play an important role in legal translation of these ideas into what we find in the Maastricht Treaty.

Shortly before the approval of the Treaty, at the special meeting of the European Council in Rome on the 27th and 28th of October 1990, a document was presented, in which European citizenship was understood to complement national citizenship, as a status attributed to those who already have the nationality of a member state. Following a new Spanish proposal from the 21 st of February 1991, the idea began to circulate that defining the new status of European citizenship ought to be done by inserting a new title in the Treaty that the member states were now entering into. Issues relating to citizenship would, therefore, become a European policy. The political will to institute this new status civitatis was undeniably present at the time, but it was not until the Maastricht Treaty in 1992 that it was expressed in a legally binding text. 
The Treaty establishing the European Community, better known as the Maastricht Treaty, ascribes a series of rights to citizens of the member states in the second part relating to citizenship: Articles. 18-21 TEC. ${ }^{5}$ These establish, first of all, the right to free movement within the Union (Article 18 TEC; now TFEU Article 21), the right to vote and stand in elections both at the local and at the European level at the same conditions as first country nationals (Article 19 TEC; now TFEU Article 22). The Treaty also provides for the right to consular protection by member states in a third country where the right-holder's home state is not represented (Article 20 TEC; now TFEU Article 23), as well as the right to petition the European Parliament and to appeal the European ombudsman in cases of maladministration (Article 21 TEC; now TFEU Article 24). The final provisions of Article 22 TEC (now TFEU Article 25 ) provide that provisions may be adopted to strengthen or to add the rights laid down. It is thus an open list, a fact that is confirmed by other aspects too.

In fact, the rights listed in the second part of the Maastricht Treaty are not exhaustive of the status of the European citizen. This is not merely because of subsequent regulatory actions and later treatises, such as the Amsterdam Treaty, the Charter of Fundamental Rights of Nice or the Lisbon Treaty that have indeed added rights. It is so also because a series of legal positions have been ascribed to the European citizen in the caselaw of the European Court of Justice. European citizens do not only have the rights listed under the heading relating to European citizenship in the treatises. These rights are also determined by case-law and by secondary legislation, that is, the legal acts, listed in Article 288 TFEU, including regulations, directives, decisions, recommendations and opinions.

\subsubsection{A Farewell to Traditional International Law}

European citizenship differs both from nationality in unitary states and from dual citizenship commonly found in federal systems (See, e.g. BarYaacov 1961; Garot 1999; Hansen 2002; a comparison in Schönberger 2005). There are some structural reasons why.

Much emphasis was laid on the fact that, originally, the recognition of the individual's legal status in Community law did not differ from the legal status of subjects under international law (Jacobs 1976; Janis 1984; Nascimbene 1986; Lippolis 1994; Trevisani 1995; Cordini 2003). European law, however, broke with the tradition of international law, a 
matter which did not fail to impact on the legal status of individuals. The rules adopted by the Union are directly applicable to individuals and individuals may use, in some cases without reference to the state organs, the Court of Justice and the Court of First Instance. Rights can be claimed by the individual, not only against EU and member state institutions, but also against private persons and bodies. ${ }^{6}$

European law differs from international law in allowing direct individual access to the justice system. This fact provides some insight into what was considered to be the very point of introducing European citizenship: In the 'common provisions' in Title I, the parties to the Treaty are 'resolved to create a citizenship common to the nationals of their countries' and 'to strengthen rights of the nationals of their member states through the introduction of a citizenship of the Union.' The provision of rights is therefore a central aspect of European citizenship.

There are also other features of European citizenship that sets it apart from traditional constructs. There are reasons inherent to the very structure of the EU, and reasons inherent to the development of the case-law by the European Court of Justice:

First, the different legal positions associated with Union citizenship have a common principle: freedom from discrimination on grounds of nationality. In European law, nationality is not considered a relevant criterion for ascribing to individuals different legal positions, other things being equal, whereas differential treatment on grounds of nationality is a core feature of international law. In the second part of the consolidated versions of the Treaty on the Functioning of the European Union (TFEU), under the title 'Non-discrimination and Citizenship of the Union,' this principle is defined in the following terms: 'Within the scope of application of the Treaties, and without prejudice to any special provisions contained therein, any discrimination on grounds of nationality shall be prohibited' Article 18 TFEU (ex Article 12 TEC).

This is an atypical principle in this context. Traditionally, differential treatment on the grounds of nationality is precisely what status civitatis enables. The point of making the distinction between nationals and non-nationals is to allow differential treatment. Citizenship, or status civitatis to use the legal term of art, is a status that is recognised only by those having some privileged relationship with the community. Originally this relationship was conceived as a relationship of perpetual allegiance linking a territory's subjects to their ruler (Vanel 1951, p. 21) but, over the centuries, it came to be understood in national 
terms, ${ }^{7}$ even though formally the introduction of the principle of nationality in international law occurs rather late. ${ }^{8}$ Over the last couple of centuries - and with significant difficulties in colonial settings - the prevailing idea was that differential treatment on grounds of nationality did not equate to discrimination. To the contrary, nationality was admittedly considered to offer justification, or good reason, to treat individuals differently. It is on this backdrop that the right to non-discrimination in European law can be said to stand in discontinuity with this traditional assumption that most forms of status civitatis rely on.

Second, the case-law that the European Court of Justice has developed on matters relating to citizenship departed in significant ways from the standard elaborated in international law. In European law, formal recognition of the status trumps the so-called effectiveness principle which otherwise rules international law. Under international law, in particular with reference to Article 5 of the Hague Convention from 12th April 1930, ${ }^{9}$ the principle of effectiveness applies to the resolution of questions of citizenship (See, e.g. Quadri 1936; Bastide 1956; Glazer 1956; Maury 1958; Weis 1979; Carrera Nunez and De Groot 2015). In the event of contested citizenship due to multiple nationalities, residence ought to be guiding in order to identify the legal regime that applies to the individual. This is done by verifying the person's so-called habitual residence. The principle of effectiveness was reiterated, and took on this form, following the famous Nottebohm ruling from 1955 by the International Court of Justice. Here is a summary of the famous case:

Friedrich Nottebohm was born in 1881 in Hamburg as a German citizen. In 1905, he emigrated to Guatemala, where he successfully ran his business. He maintained close ties both professionally and personally, with Germany and Liechtenstein, where his brother moved in 1931. Several family members naturalised in Guatemala, but Friedrich Nottebohm, fearing that Guatemalan citizenship would harm his business, moved to Liechtenstein in 1939 and applied for naturalisation. Here he obtained naturalisation ex iure pecuniae a month after the outbreak of war; a conflict that he would witness from a safe distance, that is from Guatemala. Being a German, he was arrested by US order in October 1943 and deported to the USA, where, without a trial, he was held for two years and three months while his belongings were confiscated and sold in Guatemala. After a series of appeals in Guatemalan courts, Nottebohm was able to obtain the diplomatic protection of Liechtenstein. In 1951, Liechtenstein presented an appeal before the international court of justice. 
At the outset, it was necessary to determine whether Liechtenstein could grant its diplomatic protection to Nottebohm. In denying the existence of a legally significant bond with Liechtenstein, the Court, in line with already mentioned Hague Convention, gave a definition of citizenship based on the principle of effectiveness: "nationality is a legal bond having as its basis a social fact of attachment, a genuine connection of existence. ${ }^{10}$ This definition is the one currently adopted in international law and it is known as the doctrine of genuine link.

It is this doctrine that the European Court of Justice distances itself from in establishing its case-law on Union citizenship. Its case-law departed from the principle of effectiveness with the Micheletti ruling. ${ }^{\text {II }}$ Here are the facts of the case: This ruling concerned Mario Vicente Micheletti, an Argentine dentist holding an Italian passport ex iure sanguinis who was refused a permanent residence card from the delegación del gobierno of Cantabria in Spain in March 1990. The appeal was presented before the Tribunal Superior de Justicia in the same Spanish region, requiring the administrative decision to be cancelled, in addition to the recognition of his right to obtain the residence card, a conditio sine qua non for the exercise of the profession, and to request, for other family members, the issuance of the residence certificate. In a preliminary ruling procedure, the Spanish court raised the issue of a conflict between Community law and Article 9 of the Spanish Civil Code, under which and in accordance with international law - in cases of multiple nationality, the citizenship that prevails is that of state in which the person had her former habitual residence before arrival on Spanish territory; in this case, Argentina. However, the judges in Luxembourg considered that the provisions of Community law precluded a member state from refusing to grant the benefit of 'community rights' to an individual in possession of both the nationality of a member state and that of a third country, on the sole basis that the member state did not recognise the person to be a second country national, that is, a person having the nationality of another member state.

Basically, under EU law, a member state may not decide who are to be considered as nationals of another member state and therefore no additional criteria can be added to assess citizenship, such as the genuine link doctrine: Merely having the nationality of a member state is sufficient to be recognised by the European legal system as a second country national (See, e.g. Borras Rodriguez 1993; Iglesias Buhigues 1993; Jessurun d'Oliveira 1993; Ruzié 1993; Carrascosa 1994). 
Apart from the reasons mentioned, inherent to the structure of the EU and to the development of the case-law of the European Court of Justice, there is yet another reason for differentiating between European citizenship and common forms of status civitatis. It pertains to how the status was introduced into EU law. Indeed, at Maastricht, when the Treaty on the European Community was signed, a choice had been made about how to design the access gate to this new citizenship. The designers shaped the access gate so as to make European citizenship a derivative status. In a nutshell, there are 28 ways to access the status.

\subsection{The Derivative Character of Union Citizenship}

European citizenship is a status that has a very specific character: It is derivative. A person gains access to the status by already having access to another status: that of national of a member state for the purposes of $\mathrm{EU}$ law. The Article 20 TFEU (ex Article 17 TEC) provides the following: 'Citizenship of the Union is hereby established. Every person holding the nationality of a Member State shall be a citizen of the Union. Citizenship of the Union shall be additional to and not replace national citizenship.' This position was reiterated by the Declaration no 2 that was annexed to the Treaty of Maastricht on nationality of a member state, according to which 'the question whether an individual possesses the nationality of a Member State shall be settled solely by reference to the national law of the Member State concerned.' So member states retain the competence to define criteria for acquisition and loss of their own nationality. Nationality of a member state is therefore a necessary criterion for the acquisition of European citizenship. This derivative nature of EU citizenship confers upon it the quality of a complementary status, different from dual citizenship status common in federal states.

An often-repeated claim is that the choice of instituting European citizenship in this derivative way, via member state legislation, was the easy way out from the political perspective. It was not the only option on the table. In the 1970s, for example, there had been suggestions linking the status of European citizenship to the principle of ius soli, bestowing a birth-right status upon those born in the EU. ${ }^{12}$ In the Nineties this way appeared to be politically tortuous; thus the option of a derivative and complementary status. The cost of this option is that different legal norms appear to be coexisting in a non-subordinate 
manner. For some, EU law and domestic law would even constitute competing norms (e.g. Evans 1991).

To limit state discretion in this area would have required harmonisation of domestic legislation on acquisition and loss of nationality. The harmonisation of nationality laws is important if the point is to prevent possible conflicts between the different domestic laws, to limit the possibilities of states to indirectly influence common rules, or to limit states' possibilities to exercise discretion when granting access to European citizenship for third county nationals (Nascimbene 1998). No such harmonisation occurred spontaneously. However, some efforts in this direction were made outside the framework of the European Communities. As a result of the work of the Council of Europe, an international treaty was signed in Strasbourg on the 6th of November 1997: The European Convention on Nationality (Schade 1995; Sabourin 1999).

It is worth noticing that the wording of the Article 20 TFEU has changed in the course of time: European citizenship is not merely 'derivative' (Treaty of Maastricht) but then also 'complementary' (Treaty of Amsterdam) and, after the Treaty of Lisbon, EU citizenship is said to be 'additional' (Geogiadou 2015, p. xix). Consider also that the abovementioned declaration on nationality was removed from the annex of the TEU after entry into force of the Lisbon Treaty.

This change is, to a great extent, the reflection of the development of the case-law (e.g. Rottman), according to which EU member states are not unbounded in stripping their own nationals of nationality in ways that would violate Union law. To be precise, the question whether an individual possesses the nationality of a Member state is no longer settled solely by reference to national law. So whereas in determining loss of citizenship states need to take into account EU law, and in particular general principles of EU law (such as the principle of proportionality), it is safe to say that nationality laws of member states is the legal source par excellence that determines access to the status. So supranational scrutiny of state discretion in this area is increasing, but this does not imply that states do not have discretion in defining their citizenship policy. The same year the Treaty of Lisbon came into force, a court ruling by the authoritative German constitutional court confirmed this view. In its 2009 Lissabon Urteil, the Bundesverfassungsgericht ruled that citizenship laws are to be considered 'core sovereignty' (Mindus and Goldoni 2012).

The fact that member states control access to the status may seem straightforward, but it is also a source of intricacies: There are 28 access 
gates to the status. The choice of using mere lexical reference to Member State nationality laws in Article 20 leaves the Herren der Verträge (Masters of the Treatises), in principle, free to determine the access criteria. There are several consequences.

A first consequence is that even though it is often claimed that all nationals of member states are European citizens, it is more accurate to say that a Union citizen is a national of a member state for the purposes of European law. Member states aiming to deprive of rights certain minority groups among their citizens have been able to engage in the inelegant practice of bringing this kind of unilateral declarations on the meaning of nationality for the purposes of EU law. ${ }^{13}$ Indeed, the design-choice made in Article 20 (ex Article 17 TEC) left member states free to influence indirectly the personal scope of application of Community legislation through the application of their nationality laws. This explains why despite the fact that Article 20 provides that the citizen of a member state is also a Union citizen, there are citizens of member states that are not European citizens: e.g., the inhabitants of Faro Islands. The people of the Faro Islands are Danes but not EU citizens. The Danish government added a protocol specifying that 'the Danish nationals' of the islands were not 'nationals for the purposes of Community law.' ${ }^{14}$ In sum, nationality of a member state is a necessary, albeit insufficient, criterion for acquisition of Union citizenship. To be sufficient, absence of unilateral declarations on the meaning of nationality for the purposes of EU law is required.

The design-choice also implies that - since we are in a setting in which no additional criteria may be added, following the break with the genuine link doctrine (see previous section) - member states are obliged to accept as second country nationals those who hold citizenship of any other member state, even though the first member state has no say in who gets to enjoy the status of national in that second state. Consider that as a result of the Spanish option right for the children of former Spanish nationals born in Spain (Art. 20 of the Spanish Civil Code), Fidel Castro could opt for European citizenship without moving from Havana (De Groot 2004, p. 7). No member state except Spain has a say on this matter.

Another puzzling case that has been discussed, and that might have some traction in a post-Brexit scenario, is this: What would happen if a member state would naturalise a significant part of the population of a state, which is not a member of the Union, without first consulting Brussels? For example, what happens if the Netherlands were to grant Dutch citizenship to the entire population of Surinam (De Groot 2004, p. 7)? It is not always clear 
what European law requires in relation to citizenship. What would have been the reaction of the Commission and the member states if Cyprus had not been accepted as a member and Greece would have granted citizenship to all Cypriots of Greek origin (Kotalakidis 2000, p. 299)?

Finally, mention ought also to be made of the fact that one of the parameters of representation in the Union is member states' population size. Depending on how population is defined (residents, EU citizens, nationals...), population size changes. It is susceptible of fluctuating considerably. Consider the fact that Greece, Hungary, Ireland but also Italy and Spain have a considerable number of expatriated citizens, while in other countries there is a significant presence of third country nationals. The relative 'weight' of the member state within the Union depends, albeit in a mediate way, on how access to nationality in these different countries is regulated and on how nationality law and immigration policies are designed. There is leeway for gerrymandering here.

Leaving the choice of designing the access gate to domestic law-makers might have been the easy way out in 1992, but today it seems to raise a lot of questions. Unclearness, in various forms, hoovers above the construct and specifically around the implications surrounding the derivative character of European citizenship. Much clearer are, however, the entitlements associated with the status.

\subsection{Entitlements Connected to the Status}

What holds EU citizenship rights together is the principle of non-discrimination on grounds of nationality (Art. 18 TFEU). The entitlements connected to EU citizenship share the assumption that the nationality a person holds is irrelevant for the purpose of enjoying the rights attributed by the Union. In this sense, European citizens are equal before EU law in their citizens' rights.

Over the years, we have witnessed an extension, or development, of rights in a two-fold way. Since its inception, the EU citizen has been subjected to a process of extension of both the number of rights and of the personal scope of the rights associated with it.

In the original Maastricht Treaty from 1992, the entitlements associated with European citizenship consisted of the following:

- The right to free movement and residence throughout the EU (and the right to work) 
- Electoral rights (active and passive) to the European Parliament in any member state

- Local electoral rights (active and passive) in the EU state of residence, under the same conditions as the nationals of that state

- The right to consular protection abroad by any member state if there are no diplomatic or consular authorities from the citizen's home state

- The right to petition the European Parliament

- The right to petition the Ombudsman

The treatises that followed have added entitlements: The Amsterdam Treaty from 1997 added the right to address the EU in any official language and to receive a reply in that same language (Art. 24). This is a right that de facto will not be challenged by Brexit since other member states use English as official language. The Nice Charter, or Charter of Fundamental Rights of the European Union, from 2000 added the right to access documents from the European Parliament, the Council and the Commission (Art. 15) and the right to good administration (Art. 41). This Charter, even though authoritative, was not recognised as binding law until it was incorporated into the Treaty of Lisbon in 2009.

The major innovation that the Treaty of Lisbon added to the list of entitlements associated with Union citizenship was, however, another: The European Citizens' Initiative (Art. 11 TEU \& Art. 24 TFEU), according to which EU citizens, representative of a cross-national opinion, present thus in several member states, can suggest to the Commission that it activate its legislative function on a particular matter. To activate a citizens' initiative, it is necessary that one million EU citizens, coming from at least seven member states, sign the initiative. Once it is activated, the Commission may decide to propose legislation as a result of it.

Entitlements have not only become more numerous, but they have also come to be interpreted as covering a higher number of persons and situations. This is largely due to the activity of the European Court of Justice, which has often extended the personal scope of entitlements. Generally speaking, the case-law has often taken on a kind of avant-gardism in pushing EU citizenship beyond the merely economically motivated concept. ${ }^{15}$ Many are nonetheless unimpressed by its success in doing so. Without any claim to 
exhaustiveness, key rulings in which the Luxembourg Court played an active role include the following.

In the ruling Rudy Grzelczyk (C-184/99), the court declared that 'EU citizenship is destined to be the fundamental status of nationals of the Member States.' Non-economically active citizens had restricted rights to residence because of secondary law. In 1999 the ruling Baumbast (C-413/99) established that residence rights derive directly from the EU Treaty. Secondary legislation can limit this right but only in observance of the principle of proportionality. In the ruling $Z h u$ \& Chen (Case C-20/02), it was found that primary caretakers of minor EU citizens have a residence right: more precisely, it was found that denying residence to the third country national mother of a minor EU citizen 'would deprive the child's right of residence of any useful effect.' In Ruiz Zambrano (Case C-34/09) the Court supplemented the protection of the status of Union citizenship with the requirement that the substance of rights attached to the status be enjoyed:

Article 20 TFEU precludes national measures which have the effect of depriving citizens of the Union of the genuine enjoyment of the substance of the rights conferred by virtue of their status as citizens of the Union. A refusal to grant a right of residence to a third country national with dependent minor children in the Member State where those children are nationals and reside, $[\ldots]$ has such an effect.

The court resorted to the 'substance' of European citizenship to ground the entitlement of a third country national to reside and work in Belgium as the father care-taker of two children who had been born nationals of Belgium in order to avoid statelessness that would have followed from being born by Colombian nationals who did not reside in Colombia (Colombia being a country applying ius soli quite strictly). However, the genuine substance doctrine has a quite limited ratio decidendi and is not likely to be applied broadly. Recently, the Court of Justice seems to have taken a more restrictive view: in Dano (Case C-333/13), through a restrictive interpretation of existing legislation, so-called benefit tourism was ruled out, by providing that 'persons exercising their right of residence should not, however, become an unreasonable burden on the social assistance system of the host Member State.'

A highly significant ruling for the arguments made in the following chapters is Janko Rottman v. Freistaat Bayern (Case C-315/08), 
illustrated in Chapter 6. Here it suffices to say that the case regarded loss of EU citizenship. The Court of Justice concluded that 'a citizen of the Union who is faced with a decision withdrawing his [citizenship], and placing him $(\ldots)$ in a position capable of causing him to lose the status conferred by Article 17 EC [Article 20 TFEU] and the rights attaching thereto falls, by reason of its nature and its consequences, within the ambit of European Union law. ${ }^{16}$ Since Rottman, member states are subjected to the general principles of European law in matters such as loss of Union citizenship. This means that member states are not unbounded in denationalising or imposing loss of status civitatis. This, to some, is a first crack in the idea that nationality law belongs to the field of 'core sovereignty' to use the phrasing of the German constitutional Court.

Some of the rights we are dealing with here were recognised before being proclaimed as rights associated with Union citizenship. For instance, the right to petition was first introduced into the European Coal and Steel Community in 1953. With the exception of electoral rights, the rights associated with Union citizenship are to a considerable extent a systematisation of already recognised entitlements. This is true for freedom of movement, the right of residence and the right of petition.

Do notice also that non-discrimination on the grounds of nationality applies independently of residence on Union territory. This means that, given that Article 20 TFEU does not make any reference to residence, the personal scope of European citizenship cannot be limited with reference to residence, as shown in Eman \& Sevinger. ${ }^{17}$ This has some importance here because it implies that Brexit cannot affect non-territorial rights of EU citizens as such, but only those rights the exercise of which is strictly territorial, most notably protections linked to freedom of movement.

The entitlements listed above are the major rights associated with European citizenship in the Treaties. British nationals, having no other member state nationality to rely on, and who are residing in the UK, would effectively be deprived of these rights in a non-negotiated Brexit scenario. They would lose rights associated with freedom of movement and residence, voting rights for the elections of the European Parliament, consular protection by another member state, right to adhere to European citizens' initiatives. Jurisprudentially developed protections, such as the right to export benefits and entitlements tied to nationality to a host member state ${ }^{18}$ and the right not to be burdened, or discriminated for having exercised the freedom to move, ${ }^{19}$ are entitlements that would also be lost together with the status of Union citizen. 
British citizens, without a second member state nationality, who reside in another member state, will also lose these rights, but they will not differently from British citizens in the UK - lose rights associated with EU citizenship whose personal scope is over-inclusive in respect of having the nationality in a member state. Some rights associated with European citizenship are recognised to all residents, not to all having the nationality of a member state. Entitlements that have this characteristic include the right to petition Parliament and the Ombudsman, the right to access documents from European Parliament, Council and Commission and the right to good administration. UK nationals in the Union would retain these rights also as third country nationals. Moreover, they will lose voting rights in local elections in many member states, but not all since some countries allow non-national franchise.

Special mention needs to be made of the right to freedom of movement. It is often cast as the core of the EU citizens' rights or the most significant right. It is a transnational right, linked to the crossing of borders. While other rights connected to EU citizenship can be exercised in loco by static EU citizens, free movement presupposes the crossing of borders by mobile EU citizens. It immediately follows from the so-called four freedoms. When it was framed as a right of the European citizen at Maastricht, the innovative character laid in the extension of the personal scope of a right that already existed. In fact, the EEC Treaty attributed the right of free movement only to certain categories of workers; more specifically, to employees (Art. 39-42 TEC), self-employed (Art. 43-48 TEC) and service providers (Art. 49-55 TEC). In the Nineties, the personal scope was extended to include also potential workers, such as students, and those benefitting from services, such as pensioners. A person's economic ability provided the reason for the limitation of the personal scope of the right to free movement. Nevertheless, free movement significantly extended over the years, first by effect of the case-law, and then by means of legislation. This change relegated economic activities to a secondary role in the interpretation of Community law and consequently the number of categories admitted to freedom of movement increased.

Today, freedom of movement and residence is not an entitlement strictly linked to Union citizenship. Its ratio personae is both over- and underinclusive. It is under-inclusive because it is not recognised unconditionally to Union citizens, since there are Union citizens that may not exercise the rights connected with it. ${ }^{20}$ It is over-inclusive because the personal scope of the freedom of movement includes individuals who do not have 
EU citizenship. In fact, a number of third country nationals are covered by the acquis in relation to freedom of movement: Either because their stay is short; ${ }^{21}$ or because of their personal situation or qualification (e.g. blue card, intracorporate transfers, long-term residents, researchers, students). It is therefore not entirely correct to call it an EU citizenship right, even though it is unquestionably an entitlement much appreciated by mobile Europeans.

Regardless of whether the rights of Union citizenship are to be understood as the legal entitlements the personal scope of which coincides with those having EU citizenship or if we are to take the label in a broader meaning, the point remains that these entitlements include rights of a very different nature (including liberties, powers, protections etc.) and type (civil, political, social, etc.); having different grounds (systematisation, mutual recognition, federal vocation, etc.) and being different in character (transnational, supranational, etc.) and scope (all nationals of member states, all residents, all having health insurance and not being threat to public safety, etc.). The political bottom-line of this set of entitlements is not different from any other set of rights. As Maas stressed a decade ago: 'as long as the resulting supranational citizenship continues to be based on a popular bargain among member states rather than enjoying widespread popular support, however, the rights of the common citizenship remain endangered in the same way that citizenship rights everywhere remain contingent upon continued support from leaders and publics' (Maas 2007, p. 6).

\subsection{Conclusion}

The Maastricht Treaty introduced a new status, that of the European citizen, in 1992. A person holds European citizenship if she is a national of a member state for the purposes of community law. Those who hold this status enjoy a number of rights.

Some rights are associated with Union citizenship even thought their personal scope of application does not coincide with those individuals who hold nationality of a member state, the conditio sine qua non of access to Union citizenship. Such rights include the right to petition Parliament and the Ombudsman, the right to access documents from European Parliament, Council and Commission and the right to good administration. It is important is to notice that the rights associated with Union citizenship include transnational rights like freedom of movement. 
Freedom of movement is both over- and under-inclusive compared to the category of persons holding the nationality of a member state.

Other rights are more properly called 'citizens' rights' since they are only held by those who have the nationality of a member state. Such rights include political rights reserved for those having nationality of a member state, such as the right to vote and stand in election for second country nationals in local elections, the right to vote and stand in the elections of the European Parliament, and the right to adhere to a Citizens' initiative. These rights are called supranational because their purpose is to give political voice across borders.

The conclusion to draw from this swift overview of the entitlements connected with European citizenship is that the claim according to which having European citizenship or not has no impact on the rights one may hold is false. In the case of Brexit, exiting the Union means that all European citizens of British nationality risk losing rights associated with Union citizenship. Therefore it is misleading to claim that 'triggering Article 50 will not dilute or diminish anyone's statutory rights' (Tomkins 2016).

When first introduced, European citizenship was often depicted as being the world's first post-national status (Soysal 1994). It is connected to entitlements that may rightly be called supranational and transnational, but it is dependent on the nationality laws of European member states so therefore the characterisation using the prefix post might be a bit misleading. A better characterisation would be to say that European citizenship is a status civitatis, the criteria determining the access to and loss of which, are determined at the domestic level. It is also a status sui generis. It differs from nationality in unitary states and from dual citizenship in federal settings. Finally, it is connected to entitlements that are different in kind. We may call it a birth-right status in a multi-level polity. It is this status that some now fear losing. Next, let us try to understand what more precisely they fear.

\section{Notes}

1. Bulletin of the European Communities, suppl. 5, 1975.

2. The common passport policy, which begun in the 1970s, is of considerable importance to what has been called 'the practice of citizenship' (streamlining practices for citizens of member states who reside in other member states). This policy aimed to enable the use of ID cards instead of passports within Community borders and equal treatment of nationals of member states by 
third countries. The European Council approved the unifying passport policy at the Luxembourg Summit in 1979. In occasion of the Paris summit in 1974 and the Rome 1975 summit, the European Parliament pushed in this direction too. The delay in adopting the policy depended on the fact that passports fell into the exclusive competence of member states since it belonged to foreign policy.

3. See Bulletin of the European Communities, suppl. 7/75, Towards the Europe of Citizens.

4. See Bulletin of the European Communities, suppl. 1/1976, European Union.

5. The Treaty of Lisbon introduced, as known, a different numbering system so these articles are now to be found in the TFEU Art. 20-24. (ex Article 17 TEC), Article 21 (ex Article 18 TEC), Article 22 (ex Article 19 TEC), Article 23 (ex Article 20 TEC), Article 24 (ex Article 21 TEC).

6. See e.g. Defrenne c. Sabena (Case C-43/75 ECLI:EU:C:1976:56).

7. Here it is worth recalling that one of the first, if not the first, case brought before a court in which nationality was discussed concerned the UK: The case of the post-nati or Calvin's case opposed Edward Coke and Francis Bacon in 1608 on the issue of whether the founding of the UK had also led to the creation of a single status civitatis, if, that is, despite the diversity on the 'national' level, Scots and Englishmen were to be considered subjects with the same 'citizenship.' See Gough 1955; Wheeler 1947; Price 1997; Everson 2003; Cohen 2010.

8. It was not until January 1851 that Pasquale Stanislao Mancini, in his prolusion at the University in Turin, Del principio di nazionalità come fondamento del diritto delle genti, formulated the principle of nationality as the basis of authority relationship between the individual and state: The state becomes the institutional expression of the nation, providing the ideological reason for the Risorgimento movement in the unification of Italy. See Mindus 2014, Chapter 3.

9. Art. 5 states: 'Within a third State, a person having more than one nationality shall be treated as if he had only one. Without prejudice to the application of its law in matters of personal status and of any conventions in force, a third State shall, of the nationalities which any such person possesses, recognise exclusively in its territory either the nationality of the country in which he is habitually and principally resident, or the nationality of the country with which in the circumstances he appears to be in fact most closely connected.'

10. CIG Nottebohm (April 6, 1955) Liechtenstein v. Guatemala, full text available at http://www.icj-cij.org/docket/files/18/2674.pdf (last accessed 7 November 2016).

11. Mario Vicente Micheletti v Delegación del Gobierno en Cantabria (Case C-369/90).

12. See 1972 Italian Project for a Convention Instituting a European Citizenship [Progetto italiano per una convenzione istitutiva di una cittadinanza europea] in Sica 1979. 
13. The ability to disconnect member state nationality from EU citizenship, although confirmed in Kaur, is much more difficult for the member states to use after Rottmann. See below and for more details Chapter 6 .

14. Protocol n. 2 to the Act of Accession, relating to the Faro Islands, art. 4, 1972 (OJ L 73 163).

15. See e.g. Baubast (C-413/99), Martínez-Sala (C-85/96), Grzelczyk (C-184/99), Garcia Avello (C-148/02) and Bidar (C-209/03).

16. Case C-135/08 Janko Rottmann v Freistaat Bayern [2010] ECR nyp, $\$ 42$.

17. C-300/4, Eman and Sevinger, EU:C:2006:545 [2006] ECRI-8055.

18. See e.g. Case C-503/09, Lucy Stewart EU:C:2011:500.

19. See e.g. Case C-224/02, Pusa (Opinion of A.G. Jacobs) EU:C:2003:634; Case C-406/04, De Cuyper EU:C:2006:491). For an analysis of these, see Strumia 2013.

20. See Case C-333/13 Dano EU:C:2014:2358.

21. Third country nationals holding a valid residence permit or visa have the right to move freely within the Schengen area for up to three months within a six-month period.

\section{REFERENCES}

Bar-Yaacov, N. (1961) Dual Nationality, London: Stevens.

Bastide, S. (1956) 'L'affaire Nottebohm devant la Cour Internationale de Justice', 45 Revue critique de droit international privé 607-633.

Borras Rodriguez, A. (1993) 'Comment on the Micheletti Decision of the ECJ', 92 Revista juridica de Catalunya, 584-587.

Carrascosa, J. (1994) 'Dual Nationality and Community Law: The Micheletti Case', 1 Tolleys Immigration and Nationality Law and Practice 7-12.

Carrera Nunez, S., De Groot, G.-R. (eds.) (2015) European Citizenship at the Crossroads. The Role of the European Union on Loss and Acquisition of Nationality, Oisterwijk: Wolf.

Cohen, E.F. (2010) 'Jus Tempus in the Magna Carta: The Sovereignty of Time in Modern Politics and Citizenship', 43 Political Science and Politics 3, 463-466.

Cordini, G. (2003) 'La cittadinanza europea. Profili di diritto costituzionale comunitario e comparato', 1 Il Politico 73.

De Groot, R.-G. (2004) 'Towards a European Nationality Law' in 8 Electronic Journal of Comparative Law, available at: http://www.ejcl.org/83/art83-4. html (last accessed 20 January 2017).

Evans, A.C. (1991) 'Nationality Law and European Integration', 16 European Law Review 190ff.

Everson, M. (2003) 'Subjects or Citizens of Erewhon?’, 7 Citizenship Studies 1, 65-83. Garot, M.J. (1999) La citoyenneté de l'Union européenne, Paris: L'Harmattan. 
Geogiadou, Z. (2015) 'Foreword', in S. Carrera Nunez, G.-R. De Groot (eds.) European Citizenship at the Crossroads. The Role of the European Union on Loss and Acquisition of Citizenship (ILEC), Oisterwijk: Wolf Legal Publishers.

Glazer, J.H. (1956) 'Affaire Nottebohm (Lichtenstein v. Guatemala), A Critique', 44 Georgetown Law Journal 313-325.

Gough, J.W. (1955) Fundamental Law in English Constitutional History, Oxford: Clarendon.

Hansen, R. (2002) Dual Nationality, Social Rights and Federal Citizenship in the U.S. and Europe: The Reinvention of Citizenship, New York: Berghahn Books.

Iglesias Buhigues, J.L. (1993) 'Doble nacionalidad y derecho comunitario. A propósito del asunto C 369/90, Micheletti', in M. Perez Gonzalez (ed.) Hacia un nuovo orden international y europeo. Homenaje al prof. M. Diéz de Velasco, Madrid: Tecnos, 953-967.

Jacobs, F.G. (1976) The European Law and the Individual, Amsterdam/New York: Elsevier.

Janis, M.W. (1984) 'Individuals as Subjects of International Law', 61 Cornell International Law Journal 6lff.

Jessurun d'Oliveira, H.U. (1993) 'Case-Note (Case C-369/90) M.V. Micheletti', 30 Common Market Law Review 623-637.

Kotalakidis, N. (2000) Von der nationalen Staatsangehörigkeit zur Unionsbürgerschaft. Die Person und das Gemeinwesen, Baden-Baden: Nomos.

Lippolis, V. (1994) La cittadinanza europea, Bologna: Il Mulino.

Maas, W. (2007) Creating European Citizens, Lanham: Rowman \& Littlefield.

Marquand, D. (1979) A Parliament for Europe, London: Cape.

Marshall, T.H. (1950) Citizenship and Social Class and Other Essays, Cambridge: CUP.

Maury, J. (1958) 'L'arrêt Nottebohm et la condition de nationalité effective', 23 Zeitschrift für ausländisches und internationales Privatrecht 515-534.

Mindus, P. (2014) Cittadini e no. Forme e funzioni dell'inclusione e dell'esclusione, Florence: Firenze University Press.

Mindus, P., Goldoni, M. (2012) 'Between Democracy and Nationality: Citizenship Policies in the Lisbon Ruling', 18 European Public Law 2, 351-371.

Nascimbene, B. (1986) 'Nationality Law and Citizenship', in B. Nascimbene (ed.) Nationality Laws in the European Union, London: Butterworths.

Nascimbene, B. (1998) 'Towards a European Law on Citizenship and Nationality?', in S. O'Leary (ed.) Citizenship and Nationality Status in New Europe, London: Sweet \& Maxwell.

Price, P.J. (1997) 'Natural Law and Birthright Citizenship in Calvin's Case', 9 rale Journal of Law and the Humanities 1 , Winter.

Quadri, R. (1936) La sudditanza nel diritto internazionale, Padova: Cedam.

Ruzié, D. (1993) 'Nationalité, effectivité en droit communautaire', 97 Revue générale de droit international public 107-120. 
Sabourin, N. (1999) The Relevance of the European Convention on Nationality for Non-European States in 1st European Conference on Nationality: Trends and Developments in National and International Law on Nationality, Council of Europe, 18 and 19 October 1999, available at http://www.coe.int/t/dghl/ standardsetting/nationality/Conference\%201\%20(1999)Proceedings.pdf (last accessed 7 November 2016)

Schade, H. (1995) 'The Draft European Convention on Nationality', 49 Austrian Journal of Public and International Law 2, 99-103.

Schönberger, C. (2005) Unionsbürger: Europas föderales Bürgerrecht in vergleichender Sicht, Tübingen: Mohr.

Sébastien, G. (1993) 'La citoyenneté de l'Union européenne', 5 Revue de droit public et de la science politique en France et à l'étranger 1267.

Sica, M. (ed.) (1979) Verso la cittadinanza europea, Firenze: Le Monnier.

Soysal, Y. (1994) Limits of Citizenship. Migrants and Postnational Membership in Europe, Chicago: Chicago University Press.

Strumia, F. (2013) 'Looking for Substance at the Boundaries: European Citizenship and Mutual Recognition of Belonging', 32 Yearbook of European Law 432-459.

Tomkins, A. (2016) 'Brexit, Democracy and the Rule of Law', VerfBlog, 2016/ 11/06 available at http://verfassungsblog.de/brexit-democracy-and-the-ruleof-law/ (last accessed 7 November 2016).

Trevisani, M.P. (1995) I soggetti dell'Unione Europea, Padova: Cedam.

Vanel, M. (1951) 'La notion de nationalité. Évolution historique en droit interne et en droit colonial comparé', Revue critique de droit international privé, 40.

Weis, P. (1979) Nationality and Statelessness in International Law, 2nd ed., London: Stevens \& Sons.

Wheeler, H. (1947) Calvin's Case and the Empire, (Ph.D. diss.), Indiana University.

Open Access This chapter is licensed under the terms of the Creative Commons Attribution 4.0 International License (http://creativecommons.org/licenses/ by $/ 4.0 /)$, which permits use, sharing, adaptation, distribution and reproduction in any medium or format, as long as you give appropriate credit to the original author(s) and the source, provide a link to the Creative Commons license and indicate if changes were made.

The images or other third party material in this chapter are included in the book's Creative Commons license, unless indicated otherwise in a credit line to the material. If material is not included in the book's Creative Commons license and your intended use is not permitted by statutory regulation or exceeds the permitted use, you will need to obtain permission directly from the copyright holder.

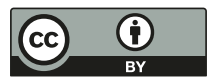

